\title{
Isolation of New Strains of Bacteria Able to Synthesize 1,3-Propanediol from Glycerol*
}

\author{
Daria Szymanowska-Powalowska ${ }^{\#}$, Agnieszka Drożdżyńska, Natalia Remszel \\ Department of Biotechnology and Food Microbiology, Poznań University of Life Sciences, Poznan, Poland \\ Email: "darszy@up.poznan.pl, agadro@up.poznan.pl,remszel@up.poznan.pl
}

Received February 7, 2013; revised March 7, 2013; accepted April 7, 2013

Copyright (C) 2013 Daria Szymanowska-Powałowska et al. This is an open access article distributed under the Creative Commons Attribution License, which permits unrestricted use, distribution, and reproduction in any medium, provided the original work is properly cited.

\begin{abstract}
The natural environment is inhabited by many species that exhibit very specific metabolic activities that may find industrial applications. The aim of the study was to select non-pathogenic cultures of bacteria of the genus Clostridium and lactic acid bacteria able to convert glycerol into 1,3-propanediol (1,3-PD). Another aim of this study was to identify the isolates that best produced 1,3-propanediol both from pure and crude glycerol. The most efficient strains identified (Cl. butyricum) were analysed on a bioreactor scale. The aim was to determine temperature conditions on the efficiency and duration of 1,3-PD synthesis. The species Clostridium were identified using amplification of the 16S rRNA coding sequence. A total of 123 isolates (of the genus Clostridium and lactic acid bacteria) were isolated; a vast majority of these were able to synthesize 1,3-PD. The best results were obtained for Cl. butyricum strain DSP1, which was isolated from the rumen of a cow fed with glycerol. The strain efficiency using pure glycerol on bioreactor scale $0.65 \mathrm{~mol} / \mathrm{mol}$ of glycerol at a temperature of $38^{\circ} \mathrm{C}$ and a constant $\mathrm{pH}$ of 7.0.
\end{abstract}

Keywords: Clostridium spp.; Bacteria Isolation; 1,3-Propanediol; Glycerol Conversion; Microflora of Natural Environment

\section{Introduction}

The instability of crude oil prices and the need for environmentally friendly production necessitate the search for alternative energy sources. Biofuels, including biodiesel, are examples of such energy sources. A waste product of biodiesel production is glycerol (bioglycerol). This hard-to-manage waste product can be used as a component of production media for bacteria that synthesize dihydroxyacetone (Acetobacter sp., Gluconobacter sp.), butanol (Clostridium pasteurianum ATCC® $6013 \mathrm{TM}$ ), propionic acid (Propionibacterium), succinic acid (Basfia succiniciproducens DD1), polyhydroxyalkanoates (PHAs) (Pseudomonas oleovorans NRRL B-14682), vitamin B12 (Propionibacterium freudenreichii ssp. shermanii) or ethanol (a nonpathogenic strain of Kluyvera cryocrescens S26) [1-8]. Crude glycerol is also used as a source of carbon for yeasts. It can be used in the growth medium

\footnotetext{
*The paper was prepared within the framework of project no. 01.01.0200-074/09 and cofounded by the European Union from the European Regional Development Fund within the framework of the Innovative Economy Operational Programme 2007-2013.

${ }^{\#}$ Corresponding author.
}

for fodder yeasts or as a substrate for the synthesis of citric acid (Yarrowia lipolytica N15), acetic acid, mannitol (Yarrowia lipolytica LFMB 19), erythritol (Yarrowia lipolytica Wratilsavia K1) and during fat synthesissingle-cell oil (Yarrowia lipolytica ACA-DC 50109) [912]. Bioglycerol may be successfully used to synthesize fumaric acid (Rhyzopus sp.) and arabitol (Debaryomyces hansenii), and it may be used as a cosubstrate for the synthesis of xylitol (Candida sp.) [13-16]. Biotechnologically important management methods for the waste left after biodiesel production include the supplementation of animal feeds (glycerol can enrich the diet) [17]. An important application for bioglycerol is for the production of 1,3-propanediol. 1,3-Propylene glycol (1,3-PD), together with purified terephthalic acid, is used in the production of polytrimethylene terephthalate (PTT), an aromatic polyester that exhibits high elastic recoveries. 1,3-PD is employed also as a supplement with low solidification properties, a solvent and a lubricant in the form of propylene glycol [18]. Presently, it is produced using chemical methods such as the hydration of acrolein (Degussa, DuPont) and the hydroformylation of ethylene oxide (Shell) $[19,20]$. 
Biotechnological methods may be employed to obtain 1,3-PD by converting glycerol using bacteria of the genera Clostridium, Klebsiella, Citrobacter, Lactobacillus [21,22]. 1,3-Propylene glycol is one of the oldest chemical products derived from biomass. The first biotechnological process described was developed in the 19th century by August Freund and entailed the fermentation of glycerin by a mixture of bacterial strains (including a Clostridium pasteurianum strain) [23]. Notably, glycerol is a natural substrate and is the cheapest substrate in the microbiological production of 1,3-propanediol. Its average price is $\$ 0.04 / \mathrm{kg}$, and, in the process of biotechnological conversion of glycerol into $1,3-\mathrm{PD}$, it accounts for over $2 / 3$ of the production costs [24]. A collaboration between two companies, DuPont and Genencor, resulted in the development of a biotechnological method of 1,3-propanediol production based on the process of direct fermentation of glucose by a genetically modified strain of E. coli [25]. Finally, in 2006, DuPont and Tate \& Lyle launched the production of 1,3-propanediol from glucose using a biocatalyst created by Genencor. The production system, whose efficiency amounted to $45,000 \mathrm{t} / \mathrm{a}(\mathrm{t} / \mathrm{a}-$ tons per annum), was located in Loudon, Tennessee (USA). The global production of 1,3-propanediol exceeds $200,000 \mathrm{t} / \mathrm{a}$ and its cost is about $€ 1.8 / \mathrm{kg}$.

Because of the increasing demand for 1,3-PD worldwide, new attractive sources of its isolation are being sought, and their appeal is based on the efficiency of glycerol (especially crude glycerol) conversion by bacterial strains. Additionally, it should be emphasized that the groups of bacteria known to synthesize 1,3-PD may have varying degrees of pathogenic potential [26,27]. Undoubtedly, this is a problem that is particularly associated with the application of these bacteria. Moreover, in the case of bacteria from the genus Clostridium, an additional problem stems from the necessity to provide completely anaerobic conditions from the time the inoculum is prepared through the process of fermentation. Additionally, the above mentioned microorganisms do not tolerate a highly acidic medium. However, lactic acid bacteria (LAB) are among the unquestionably safe microorganisms. Bacteria are also capable of heterofermentation, using glucose and glycerol as the main sources of carbon. Microorganisms that have the GRAS (Generally Recognized As Safe) status, are anaerobic, are able to synthesize 1,3-propanediol and are resistant to a low environmental $\mathrm{pH}$ are attractive alternatives to the producers described so far.

The aims of this study were to isolate new bacterial strains able to produce 1,3-PD.

\section{Materials and Methods}

\subsection{Source of Isolation}

The bacteria were isolated from the ruminal fluid of a cow from a farm in the Wielkopolska province (Poland) and the sludge from the wastewater treatment plant in Zielona Gora (Poland).

\subsection{Media}

The isolating medium for the lactic acid bacteria was MRS-Agar medium (Biocorp, Warsaw, Poland), while the bacteria of the genus Clostridium were isolated in TSC medium (Biocorp, Warsaw, Poland). Liquid MRS medium (Biocorp, Warsaw, Poland) was used for the cultivation of lactic acid bacteria, and liquid RCM medium (Biocorp, Warsaw, Poland) was used for the cultivation of bacteria from the genus Clostridium. The media were sterilized at $117^{\circ} \mathrm{C}(\mathrm{MRS})$ or $121^{\circ} \mathrm{C}$ (TSC and RCM) for $20 \mathrm{~min}$.

A rich medium, modified (without added biotin) according to Himmi et al. [28], was used in the production experiments. The medium was supplemented with pure glycerol (POCH, Lodz, Poland) at a concentration of 70.0 $\pm 1.0 \mathrm{~g} / \mathrm{L}$. In selected cases, crude glycerol (BIOPALIWA, Malbork, Poland), containing 83.5\% (w/v) glycerol and $0.3 \%(\mathrm{w} / \mathrm{v})$ methanol, was used as the main medium ingredient.

\subsection{Isolation}

The first stage in the isolation of desired strains was based on the pour-plate method. After the incubation period $\left(48 \mathrm{~h}, 32^{\circ} \mathrm{C}\right)$, single colonies that had different morphological traits and the characteristics of a given bacterium genus were collected using disposable loops. The isolated colonies of bacteria from the genus Clostridium were black, while the isolated colonies of lactic acid bacteria were milky white and tear-shaped.

The isolates were described and preserved in RCM/ MRS medium enriched with a $20 \%$ glycerol solution (at a 1:1 ratio). Samples of these isolates were frozen at $-80^{\circ} \mathrm{C}$.

\subsection{Fermentation Experiments}

\subsubsection{Culture Conditions}

After obtaining approximately 123 isolates, fermentation experiments were performed to determine their ability to produce 1,3-propanediol from glycerol. The isolates were cultivated in Hungate test tubes (for Clostridium) or Erlenmeyer flasks (for lactic acid bacteria) in the appropriate cultivation media $\left(32^{\circ} \mathrm{C}, 24 \mathrm{~h}\right)$. All the isolation treatments of bacteria from the genus Clostridium were performed in a chamber for the cultivation of anaerobic microorganisms (the Whitley MG500, Don Whitley Scientific, Shipley, United Kingdom). Isolates from the genus Lactococcus and Lactobacillus were cultured under relative anaerobic conditions in an incubation chamber. In 
the next stage, production media (RM), enriched with pure or crude glycerol $(70.0 \pm 1.0 \mathrm{~g} / \mathrm{L})$ and a $\mathrm{pH}$ indicator $(1 \%$ solution of bromocresol purple, $2.0 \mathrm{~mL} / \mathrm{L})$, were inoculated. The $\mathrm{pH}$ was regulated at 7.0 using $20 \% \mathrm{NaOH}$. The temperature of the fermentation process was $32^{\circ} \mathrm{C}$.

\subsubsection{Bioreactor Experiments}

Isolates of the genus Clostridium that were the best producers of 1,3-propanediol were employed to perform batch fermentations in $5 \mathrm{~L}$ bioreactors (Sartorius Stedim, Germany) using pure and crude glycerol. Before the onset of the experiment, selected isolates of $\mathrm{Cl}$. butyricum were cultivated in a Hungate test tube. The culture conditions were as specified in 2.4.1. The pre-inoculum was added to an inoculation jar (Duran) that was integrated into the bioreactor. The total capacity of the production medium with the inoculum (10\%) was $2 \mathrm{~L}$. Constant stirring at $60 \mathrm{rpm}$ and a $\mathrm{pH}$ regulation at $7.0(20 \% \mathrm{NaOH})$ were provided. The temperature of the fermentation process was $32^{\circ} \mathrm{C}$.

\subsection{Analytical Methods}

Samples of fermentation broth were collected and centrifuged at $10,000 \times \mathrm{g}$ for $10 \mathrm{~min}$, and the cell-free supernatants were filtered through syringe filters prior to HPLC analysis. A Hewlett Packard 1050 system equipped with a refractive index detector was used. Analyses were performed isocratically at a flow rate of $0.6 \mathrm{~mL} / \mathrm{min}$ on an Aminex HPX-87H $300 \times 7.8$ column (Bio-Rad, CA, USA) at a constant temperature of $65^{\circ} \mathrm{C} \cdot \mathrm{H}_{2} \mathrm{SO}_{4}(0.5 \mathrm{mN})$ was the mobile phase. External standards were applied for identification and quantification.

The cell concentration $(\mathrm{g} / \mathrm{L})$ was determined using a linear equation derived from the relationship of cell dry weight $\left(90^{\circ} \mathrm{C}\right.$ until constant weight) and the optical density (OD) at $600 \mathrm{~nm}$ (Analytik Jena Specord 50). The cells were collected by centrifugation $(10,000 \times \mathrm{g}$ for 10 $\min$ ) in a Hereaus Biofuge centrifuge (Eppendorf) and washed twice with distilled water.

\subsection{Bacteria Identification}

Total DNA from the bacteria was extracted using a Ge- nomie Mini AX Bacteria Kit (A\&A Biotechnology, Gdańsk, Poland) after an initial $1 \mathrm{~h}$ incubation in 50.0 $\mathrm{mg} / \mathrm{mL}$ lysozyme (Sigma, Poland) at $37^{\circ} \mathrm{C}$. Sequences encoding small subunits of $16 \mathrm{~S}$ rRNA were amplified by PCR using SDBact0008aS20 and SUniv1492bA21 primers [29]. The PCR products were purified using the Clean-up Kit (A\&A Biotechnology, Gdańsk, Poland) and sequenced at Genomed (Warsaw, Poland) using the primers used for PCR and a primer for an inner sequence (GTGCCAGCMGCCGCCCTAA). The sequences obtained were arranged into contigs and identified using the BLAST service of the GenBank database [30]. Lactic acid bacteria (LAB) were identified using biochemical tests (Pliva-Lachema Diagnostika, Brno, Czech Republic).

\subsection{Phylogenetic Analyses}

The sequences encoding the 16S rRNA of Cl. butyricum strain DSP1 were compared with the randomly selected sequences of Clostridia in GenBank. The sequences were aligned using the ClustalW program as implemented in BioEdit (version 7.0.9). The phylogenetic analyses were conducted using the MEGA 4.0 software [31]. The neighbour-joining method was used for phylogenetic reconstruction, and the p-distance was used for distance analysis. The best phylogenetic distance tree is shown.

\section{Results and Discussion}

\subsection{Isolation of New Strains}

One hundred and thirty strains of potential production importance were isolated, of which bacteria of the genus Clostridium accounted for $78 \%$ and lactic acid bacteria accounted for $6 \%$. The selected isolates of bacteria from the genus Clostridium and LAB produced 1,3-PD well. Ninety-eight percent of the isolates of bacteria from the genus Clostridium and $60 \%$ of the lactic acid bacteria could synthesize 1,3-PD from glycerol at a high level (Table 1). To determine the relationship between the best Clostridium butyricum DSP1 strain isolated from the rumen and the other Clostridium strains, a phylogenetic tree was built based on the nucleotide sequences of the genes encoding 16S rRNA (Figure 1). Most of the strains

Table 1. Results of the isolation of bacteria from the genera Clostridium and lactic acid bacteria able to convert glycerol into 1,3-PD.

\begin{tabular}{ccccc}
\hline \multirow{2}{*}{ Microorganism } & \multirow{2}{*}{ Total number of isolates } & \multicolumn{2}{c}{ The number of isolates able to convert glycerol into 1,3-PD (real) } \\
\cline { 3 - 5 } & & $0.1-15.0 \mathrm{~g} / \mathrm{L}$ & $15.1-30.0 \mathrm{~g} / \mathrm{L}$ & $30.1-40.0 \mathrm{~g} / \mathrm{L}$ \\
\hline Clostridium sp. & 104 & 102 & 50 & 11 \\
Lactic acid bacteria & 13 & 8 & 1 & 0 \\
Other $^{*}$ & 13 & 13 & 0 & 0 \\
\hline
\end{tabular}

Culture conditions: incubation temperature $32^{\circ} \mathrm{C}, \mathrm{pH} 7.0$, glycerol concentration $70.0 \pm 1.0 \mathrm{~g} / \mathrm{L}$, growth in Hungate tubes (for Clostridium) and Erlenmeyer flasks (for lactic acid bacteria). ${ }^{*}$ Not identification. 


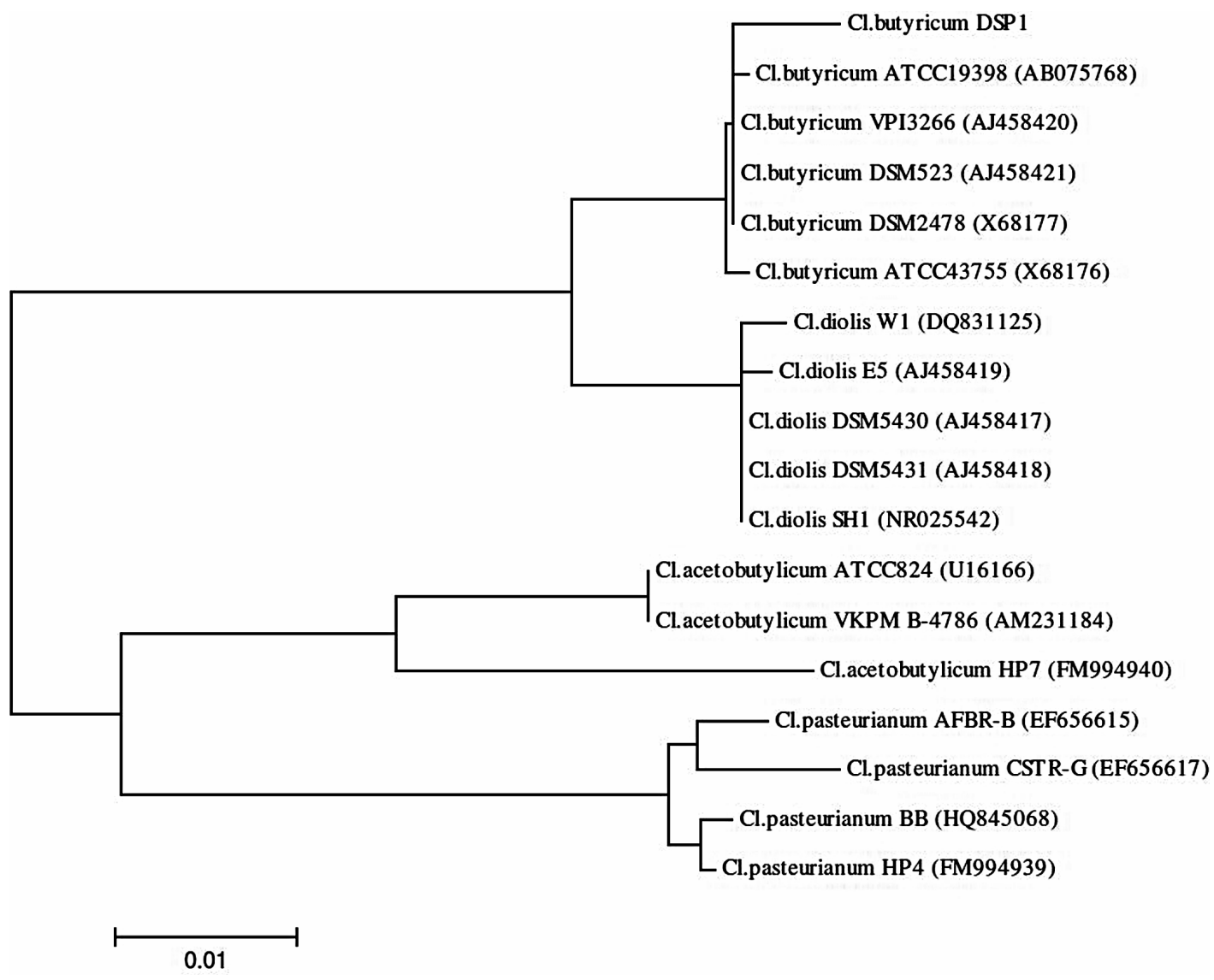

Figure 1. 16S rRNA-based phylogenetic tree showing the position of glycerol-fermenting Clostridium butyricum DSP1 among related Clostridia.

chosen from the database for the phylogenetic comparison are able to use glycerol as the sole carbon source. Among the microorganisms compared, there were strains capable of producing 1,3-propanediol (Cl. butyricum VIP 3266, Cl. butyricum DSM 2478, Cl. butyricum DSM 523, Cl. diolis DSM 5430, Cl. diolis DSM 5431 and Cl. diolis E5) [32].

The best isolates were obtained from the rumen of a cow fed with glycerol. Notably, the supplementation of animal feed with glycerol and propylene glycol is often applied in the pre- and post-partum period, which correlates with a negative energy balance in cows and other animals $[17,33]$. Glycerol may be an effective glucogenic substrate (also known as a glucose precursor) and can be directly absorbed from the rumen. It can enter the path of glucogenesis as triose phosphate while bypassing the Krebs cycle. A cow initiates this additional pathway and uses the glycerol released during they hydrolysis of triglycerides. This pathway is the most favourable for the health of the animals. Unfortunately, most glycerol in the rumen is fermented to propionates and butyrates. DeFrain et al. [34] demonstrated that glycerol was not present in the blood of cattle fed with glycerol, which suggests that it was the main source of energy for ruminal microorganisms and was not involved in glucogenesis. Notably, the natural microflora of the digestive tract consists mainly of lactic acid bacteria and Clostridium. The maximum concentration of 1,3-PD obtained $(39.1 \mathrm{~g} / \mathrm{L}$, $100 \%$ glycerol used) was from a strain of Clostridium butyricum DSP1. Similar results were reported in a batch culture using $\mathrm{Cl}$. butyricum strain CNCM 1211 by Himmi et al. [28], who obtained a maximum efficiency of 0.69 $\mathrm{mol} / \mathrm{mol}$ of glycerol. Such high efficiencies of 1,3-PD synthesis seem to be characteristic of the Cl. butyricum species only. Gungormusler et al. [35] examined a batch fermentation of $\mathrm{Cl}$. saccharobutylicum NRRL B-643 and achieved glycerol efficiency of $0.36 \mathrm{~mol} / \mathrm{mol}$. However, this study showed novelty in the isolation of bacteria from the genus Lactococcus that are able to synthesize 1,3-PD. After preliminary research, the maximum concentration of 1,3-PD obtained was $25.5 \mathrm{~g} / \mathrm{L}$. The capacity of lactic acid bacteria to produce 1,3-PD was also mentioned by other authors; however, experimental data concerned mainly bacteria of the genus Lactobacillus [36, 37]. Better results for lactic acid bacteria were obtained by Pfügl et al. [38]. A strain of Lactobacillus diolivorans generated a maximum concentration of $1,3-\mathrm{PD}-84.5$ $\mathrm{g} / \mathrm{L}$ of $1,3-\mathrm{PD}$ with an efficiency of $0.57 \mathrm{~mol} / \mathrm{mol}$ from a 
mixture of glucose and pure glycerol. The isolation of LAB strains allows for the safe production of 1,3-PD in industrial settings. Most producers of 1,3-PD that have been described have a high (Enterobacteriaceae) or low (Clostridium) pathogenic potential, which may hinder the implementation of the technologies [26,27]. However, bacteria of the genus Lactobacillus are classified as GRAS and, therefore, are safe to use in industrial processes.

The isolation results confirmed the ability of strains to synthesize 1,3-propanediol. A vast majority of the isolates obtained could synthesize 1,3-PD with an efficiency close to the theoretical efficiency. In addition, previously undescribed strains of lactic acid bacteria species that are able to utilize glycerol and synthesize 1,3-PD with a satisfactory efficiency were isolated.

\subsection{The Production of 1,3-Propanediol from Pure and Crude Glycerol by Bacteria of the Genera Clostridium and Lactic Acid Bacteria}

Industrially produced 1,3-PD should use the glycerol fraction generated by biodiesel production, which is difficult to manage. Many reports describe the inhibitory effect of crude glycerol components on microbial growth and metabolism [39-41]. Crude glycerol includes many substances that may act as inhibitors of microbial growth and metabolism. These include sodium salts, heavy metal ions, soaps, methanol and free fatty acids [40,42]. Therefore, the next steps in characterising the bacterial strains were to verify the best isolates using crude glycerol as a substrate. The results presented in Table 2 show that the production abilities of the best isolates were comparable irrespective of the main substrate type.
Figure 2 shows the kinetics of 1,3-propanediol synthesis using pure and crude glycerol for the Cl. butyricum strain DSP1.

Clostridium butyricum strain DSP1 produced the maximum concentration of $1,3-\mathrm{PD}, 100 \%$ utilization of the substrate and a conversion efficiency of $0.67 \mathrm{~mol} / \mathrm{mol}$ of glycerol. A similar efficiency was obtained for crude glycerol (the glycerol fraction). Slight differences in the concentration of 1,3-PD resulted from the content of glycerol in the glycerol fraction $(83.4 \%)$. There is an increasing number of reports on the synthesis of 1,3-PD from crude glycerol. Clostridium butyricum strain F2b can produce $48 \mathrm{~g} / \mathrm{L}$ of 1,3-PD (efficiency of $0.66 \mathrm{~mol} / \mathrm{mol}$ ) using crude glycerol [43]. Clostridium butyricum CNCM 1211 generated $63.4 \mathrm{~g} / \mathrm{L}$ of 1,3-PD with an efficiency of $0.69 \mathrm{~mol} / \mathrm{mol}$ from crude glycerol [44]. The high concentrations of 1,3-PD obtained by other authors depended on the type of fermentation conducted (fed-batch or continuous). Exceptional results were achieved by Ringel et al. [41]. The authors isolated nonpathogenic strains, Cl. butyricum AKR102a and AKR91b, that were resistant to high concentrations of 1,3-PD (approximately $100.0 \mathrm{~g} / \mathrm{L}$ of 1,3-PD using crude glycerol). Barbirato et al. [18] described a higher $(0.69 \mathrm{~mol} / \mathrm{mol})$ efficiency of 1,3-PD synthesis from waste glycerol than was obtained in this study. In another study, Gonzalez-Pajuelo et al. [45] described the effect of waste glycerol on parameters of continuous fermentation by the $\mathrm{Cl}$. butyricum strain VPI 3266. Three types of raw material were analysed: commercial glycerol $(87 \%, \mathrm{w} / \mathrm{v})$ and two types of waste differing in their glycerol content $(92 \%$ and $65 \%$, w/v). The efficiencies obtained by the authors were similar to those obtained in this study, ranging from 0.57 to 0.62 $\mathrm{mol}_{1,3-\mathrm{PD}} / \mathrm{mol}_{\text {glycerol }}$. Chatzifragkou et al. [40] described the effect of waste glycerol on the parameters of 1,3-PD

Table 2. Batch fermentation of new bacterial isolates using pure and crude glycerol.

\begin{tabular}{|c|c|c|c|c|c|c|}
\hline Strain & 1,3-PD (g/L) & But $(g / L)$ & Ace $(g / L)$ & $\operatorname{Lac}(g / L)$ & $\mathrm{Y}(\mathrm{mol} / \mathrm{mol})$ & $X(g / L)$ \\
\hline \multicolumn{7}{|c|}{ Pure } \\
\hline Clostridium butyricum DSP1 & $39.1 \pm 2.5$ & $8.4 \pm 0.9$ & $2.0 \pm 0.2$ & $3.9 \pm 0.5$ & 0.67 & $1.2 \pm 0.1$ \\
\hline Clostridium butyricum DSP5 & $36.3 \pm 1.3$ & $7.5 \pm 0.6$ & $1.7 \pm 0.2$ & $3.3 \pm 0.4$ & 0.62 & $1.1 \pm 0.1$ \\
\hline Clostridium butyricum DSP16 & $33.2 \pm 1.5$ & $6.7 \pm 0.5$ & $1.4 \pm 0.3$ & $3.2 \pm 0.4$ & 0.57 & $1.2 \pm 0.1$ \\
\hline Lactococcus garvieae DSL1 & $25.5 \pm 1.2$ & $\mathrm{ND}^{*}$ & ND & $5.5 \pm 0.6$ & 0.59 & $2.5 \pm 0.3$ \\
\hline Lactobacillus brevis DSL2 & $15.6 \pm 1.0$ & ND & ND & $9.2 \pm 1.0$ & 0.43 & $3.0 \pm 0.4$ \\
\hline \multicolumn{7}{|c|}{ Crude } \\
\hline Clostridium butyricum DSP1 & $29.1 \pm 1.7$ & $6.6 \pm 0.7$ & $1.7 \pm 0.3$ & $4.1 \pm 0.5$ & 0.58 & $1.3 \pm 0.1$ \\
\hline Clostridium butyricum DSP5 & $31.7 \pm 2.5$ & $6.7 \pm 0.7$ & $1.5 \pm 0.2$ & $3.9 \pm 0.4$ & 0.64 & $1.4 \pm 0.1$ \\
\hline Clostridium butyricum DSP16 & $27.6 \pm 2.1$ & $5.8 \pm 0.6$ & $1.3 \pm 0.3$ & $3.8 \pm 0.4$ & 0.58 & $1.2 \pm 0.1$ \\
\hline Lactococcus garvieae DSL1 & $19.8 \pm 1.2$ & ND & ND & $3.3 \pm 0.6$ & 0.55 & $2.6 \pm 0.4$ \\
\hline
\end{tabular}

Table 2 shows the fermentation conditions: fermentation duration (h), 1,3-propanediol (1,3-PD, g/L), butyric acid (But, g/L), acetic acid (Ace, g/L), lactic acid (Lac, g/L), glycerol utilization (\%), yield (mol 1,3-propanediol produced per mol glycerol consumed Y, mol 1,3-PD/molgly), maximum biomass production (X, $\mathrm{g} / \mathrm{L})$. All experimental points are presented as the mean values from duplicate experiments. ${ }^{*}$ Not Detected. 


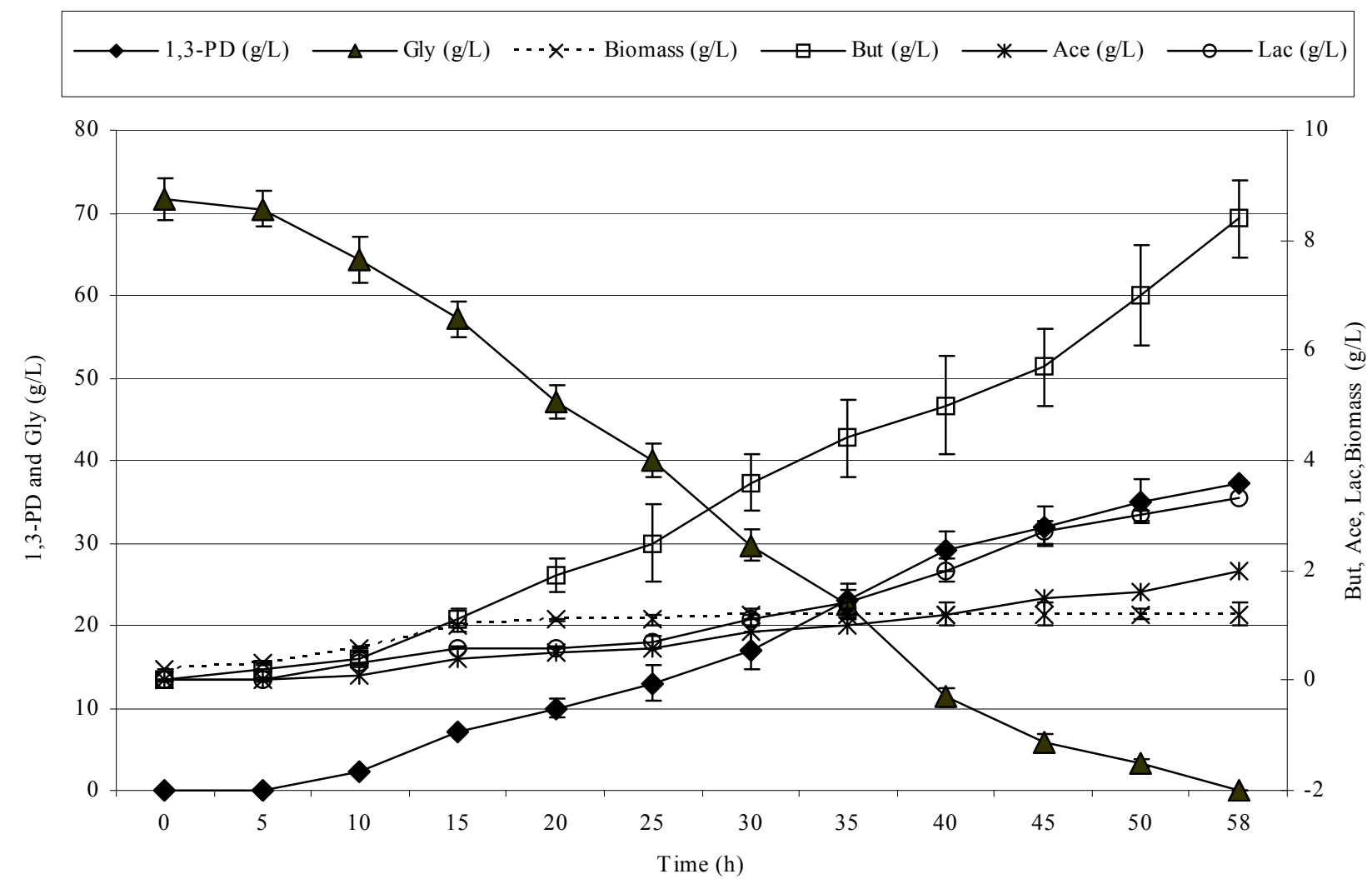

(a)

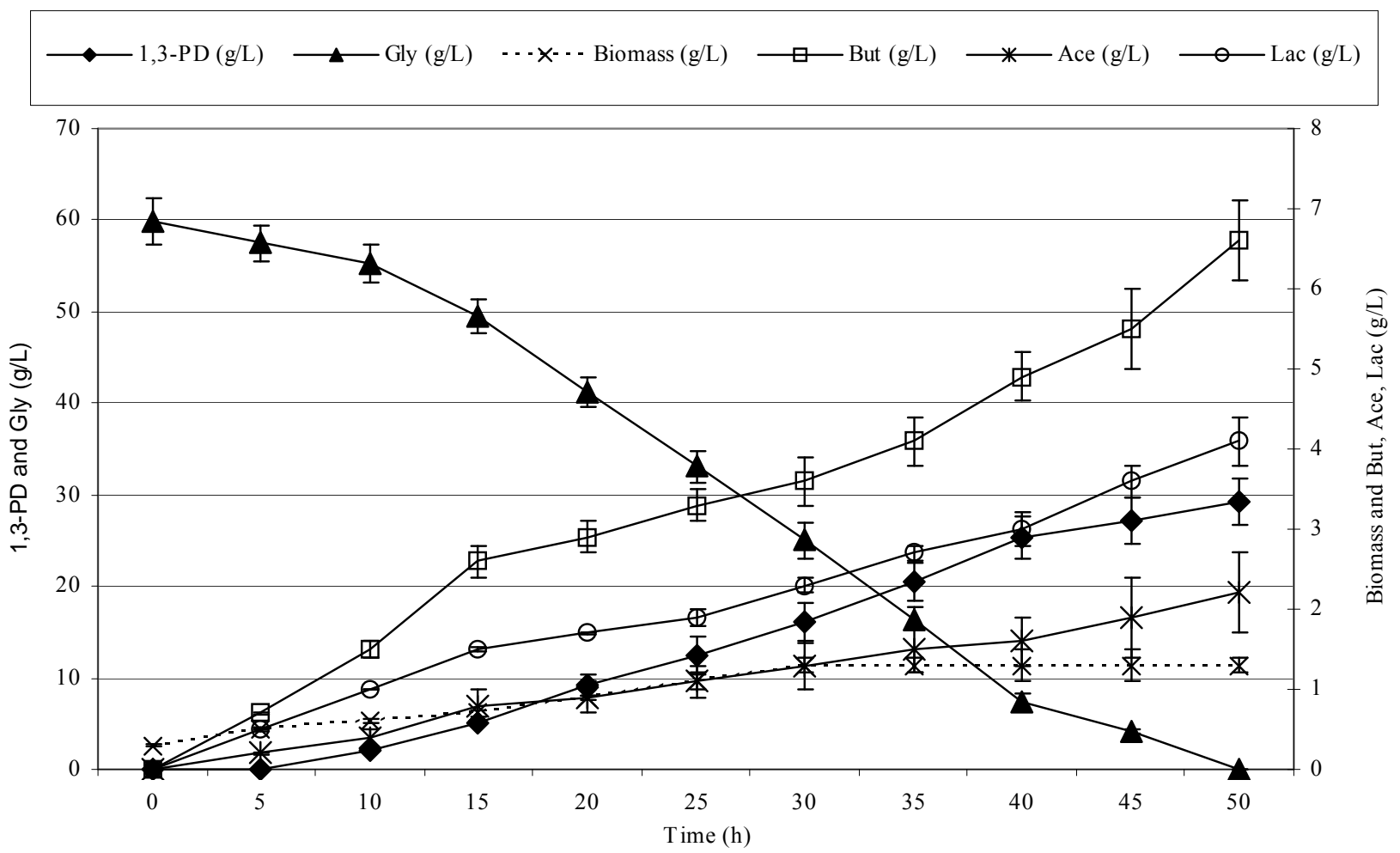

(b)

Figure 2. Kinetics of glycerol consumption and biomass, 1,3-propanediol, acetic acid, lactic acid and butyric acid production during the growth of Clostridium butyricum DSP1 on pure (Figure 2(a)) and crude (Figure 2(b)) glycerol in batch bioreactor experiments. 
synthesis for the Cl. butyricum strain VPI 1718. The efficiency of 1,3-PD synthesis for pure and waste glycerol was identical at $0.67 \mathrm{~mol} / \mathrm{mol}$ glycerol. This result is similar to those recorded in this study ( $C l$. butyricum DSP1, $0.67 \mathrm{~mol}_{1,3-\mathrm{PD}} / \mathrm{mol}_{\text {pure gly }}$ and Cl. butyricum DSP5, $0.64 \mathrm{~mol}_{1,3-\mathrm{PD}} / \mathrm{mol}_{\text {crude gly }}$ ).

The results of other authors and those presented in the present study prove that a satisfactory 1,3-propanediol synthesis efficiency of may be obtained using crude glycerol. This fact portends well for industrial implementations.

\subsection{The Influence of Temperature on the Efficiency of 1,3-Propanediol Synthesis by Clostridium butyricum Strain DSP1}

The next experiments aimed to assess the influence of temperature on the rate of 1,3-PD production. A high efficiency of 1,3-PD synthesis using $\mathrm{Cl}$. butyricum at $37^{\circ} \mathrm{C}$ has been reported $[18,28,46]$. A similar relationship was observed in this study. They were performed in bioreactors using an optimum production medium and $\mathrm{Cl}$. butyricum strain DSP1. The glycerol concentration was $70 \mathrm{~g} / \mathrm{L}$. Six temperature conditions were examined: $30^{\circ} \mathrm{C}$, $32^{\circ} \mathrm{C}, 34^{\circ} \mathrm{C}, 36^{\circ} \mathrm{C}, 38^{\circ} \mathrm{C}$ and $40^{\circ} \mathrm{C}$. An increase in the temperature from $30^{\circ} \mathrm{C}$ to $38^{\circ} \mathrm{C}$ doesn't caused an increase in the production of 1,3-PD from pure glycerol but shortened fermentation time to $33 \mathrm{~h}$ (after total glycerol utilization) (Figure 3). The maximum efficiency obtained was $0.65 \mathrm{~mol} / \mathrm{mol}$ of glycerol. Barbirato et al. [18] analysed a $C l$. butyricum strain able to synthesize 1,3-propanediol from 20 and $70 \mathrm{~g} / \mathrm{L}$ of glycerol. In the first case, the authors obtained a synthesis efficiency of $0.62 \mathrm{~mol} /$ mol of glycerol after $9 \mathrm{~h}$ fermentation at a temperature of $37^{\circ} \mathrm{C}$. In the second condition, after $28 \mathrm{~h}$, they obtained an efficiency of $0.64 \mathrm{~mol} / \mathrm{mol}$ of glycerol, which is similar to the results of this study. For a comparison, the volumetric productivity for $\mathrm{Cl}$. butyricum strain DSP1 was $1.13 \mathrm{~g} /(\mathrm{L} \cdot \mathrm{h})$ at $38^{\circ} \mathrm{C}$. Kaur et al. [47], in a fed-batch culture of $\mathrm{Cl}$. diolis, obtained an efficiency of 1,3-PD synthesis of $67.8 \mathrm{~g} / \mathrm{L}$ and a productivity of $1.04 \mathrm{~g} /(\mathrm{L} \cdot \mathrm{h})$ over $67 \mathrm{~h}$ at $33^{\circ} \mathrm{C}$, while Himmi et al. [28] obtained a maximum productivity of $1.85 \mathrm{~g} /(\mathrm{L} \cdot \mathrm{h})$ and an efficiency of $0.66 \mathrm{~mol} / \mathrm{mol}$ at $37^{\circ} \mathrm{C}$ from $\mathrm{Cl}$. butyricum strain CNCM 1211 fermented in rich medium. Metsoviti et al. [22] described a new isolate of $\mathrm{Cl}$. butyricum, NRRL B-23495, which was capable of synthesizing 1,3-PD at a concentration of approximately $11.3 \mathrm{~g} / \mathrm{L}$ within $17 \mathrm{~h}$ at $37^{\circ} \mathrm{C}$. The resulting productivity, $0.66 \mathrm{~g} /(\mathrm{L} \cdot \mathrm{h})$, is less than $50 \%$ of the productivity recorded for $\mathrm{Cl}$. butyricum strain DSP1 at $1.13 \mathrm{~g} /(\mathrm{L} \cdot \mathrm{h})$. Examination of the influence of temperature on the effectiveness and the duration of propanediol fermentation showed the optimum temperature range for ensuring high productivity. The origin of isolates may help explain the results obtained. The body temperature of farm animals ranges from $37^{\circ} \mathrm{C}$ to $38^{\circ} \mathrm{C}$, which supports the optimum metabolism of the isolated microorganisms.

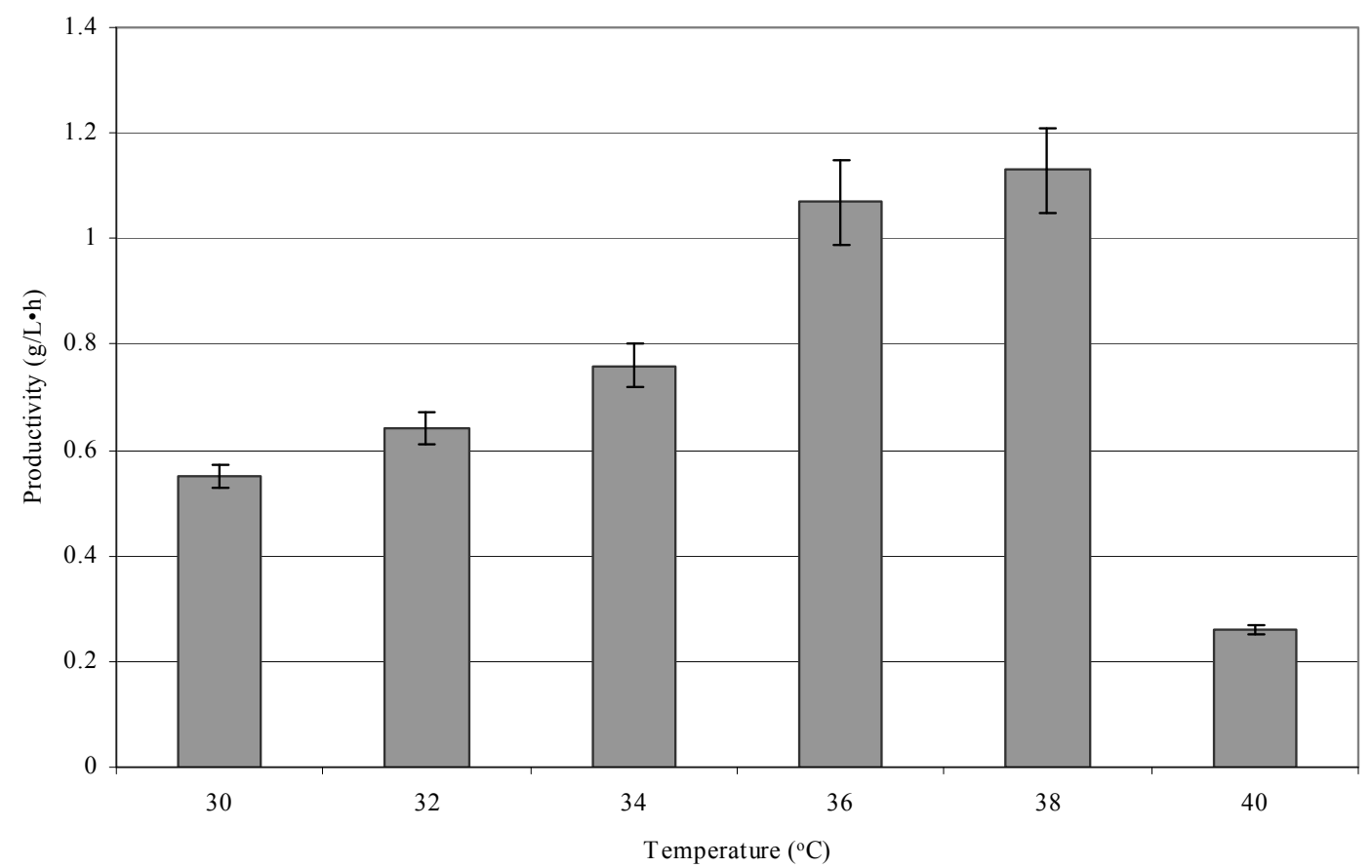

Culture conditions: initial glycerol concentration $70 \pm 1.0 \mathrm{~g} / \mathrm{L}, \mathrm{T}=30^{\circ} \mathrm{C}, 32^{\circ} \mathrm{C}, 34^{\circ} \mathrm{C}, 36^{\circ} \mathrm{C}, 38^{\circ} \mathrm{C}$ and $40^{\circ} \mathrm{C}, \mathrm{pH} 7.0$, growth in a $2 \mathrm{~L}$ bioreactor. Each point is the mean value of two independent measurements.

Figure 3. The relationship between the temperature and the fermentation process duration and productivity. 


\section{Conclusion}

New strains able to synthesize 1,3-propanediol from glycerol were isolated. In addition to the known producers of 1,3-PD (bacteria of the genus Clostridium), new isolates of the species Lactococcus, which have not yet been described, were identified. Moreover, the study confirmed the ability to use bacteria from the genus Clostridium for the synthesis of 1,3-PD from pure and crude glycerol with similar and higher efficiencies than those found in other studies. In this study, a significant relationship was observed between temperature conditions of the medium and the productivity of 1,3-PD synthesis by the best isolate, Cl. butyricum DSP1.

\section{REFERENCES}

[1] K. Nabe, N. Izuo, S. Yamada and I. Chibata, "Conversion of Glycerol to Dihydroxyacetone by Immobilized Whole Cells of Acetobacter xylinum," Applied and Environmental Microbiology, Vol. 38, No. 6, 1979, pp. 1056-1060.

[2] C. Claret, J. M. Salmon, C. Romieu and A. Bories, "Physiology of Gluconobacter oxydans during dihydroxyacetone Production from Glycerol," Applied Microbiology and Biotechnology, Vol. 41, No. 3, 1994, pp. 359-365. doi:10.1007/BF00221232

[3] A. Bories, E. Himmi, J. J. A. Jauregui, C. Pelayo-Ortiz and V. A. Gonzales, "Glycerol Fermentation with Propionibacteria and Optimization of the Production of Propionic Acid," Sciences des Aliments, Vol. 24, 2004, pp. 121-135. doi:10.3166/sda.24.121-136

[4] K. A. Taconi, K. P. Venkataramanan and D. T. Johnson, "Growth and Solvent Production by Clostridium pasteurianum ATCC $^{\circledR}$ 6013 ${ }^{\text {TM }}$ Utilizing Biodiesel-Derived Crude Glycerol as the Sole Carbon Source," Environmental Progress \& Sustainable Energy, Vol. 28, No. 1, 2009, pp. 100-110. doi:10.1002/ep. 10350

[5] E. Scholten, T. Renz and J. Thomas, "Continuous Cultivation Approach for Fermentative Succinic Acid Production from Crude Glycerol by Basfia succiniciproducen DD1," Biotechnology Letters, Vol. 31, No. 12, 2009, pp. 1947-1951. doi:10.1007/s10529-009-0104-4

[6] R. D. Ashby, D. K. Y. Solaiman and G. D. Strahan, "Efficient Utilization of Crude Glycerol as Fermentation Substrate in the Synthesis of Poly (3-Hydroxybutyrate) Biopolymers," Journal of the American Oil Chemists Society, Vol. 88, No. 7, 2011, pp. 949-959.

doi:10.1007/s11746-011-1755-6

[7] W. J. Choi, M. R. Hartono, W. H. Chan, S. S. Yeo, "Ethanol Production from Biodiesel-Derived Crude Glycerol by Newly Isolated Kluyvera cryocrescen," Applied Microbiology and Biotechnology, Vol. 89, No. 4, 2011, pp. 1255-1264. doi: $10.1007 / \mathrm{s} 00253-010-3076-3$

[8] A. Kośmider, W. Białas, P. Kubiak, A. Drożdżyńska and K. Czaczyk, "Vitamin $B_{12}$ Production from Crude Glycerol by Propionibacterium freudenreichii ssp. shermanii: Optimization of Medium Composition through Statistical Experimental Designs," Bioresource Technology, Vol. 105, 2012, pp. 128-133. doi:10.1016/j.biortech.2011.11.074

[9] W. Rymowicz, A. Rywińska and M. Marcinkiewicz, "High-Yield Production of Erythritol from Raw Glycerol in Fed-Batch Cultures of Yarrowia lipolytic," Biotechnology Letters, Vol. 31, No. 3, 2009, pp. 377-380. doi:10.1007/s10529-008-9884-1

[10] S. V. Kamzolova, A. R. Fatykhova, E. G. Dedyukhina, S. G. Anastassiadis, N. P. Golovchenko and I. G. Morgunov, "Citric Acid Production by Yeast Grown on GlycerolContaining Waste from Biodiesel Industry," Food Technology and Biotechnology, Vol. 49, No. 1, 2011, pp. 6574.

[11] A. Chatzifragkou, A. Makri, A. Belka, S. Bellou, M. Mayrou, M. Mastridou, P. Mystrioti, G. Onjaro, G. Aggelis and S. Papanikolaou, "Biotechnological Conversion of Biodiesel Derived Waste Glycerol by Yeast and Fungal Species,” Energy, Vol. 36, No. 2, 2012, pp. 1097-1108. doi:10.1016/j.energy.2010.11.040

[12] S. Papanikolaou and G. Aggelis, "Biotechnological Valorization of Biodiesel Derived Glycerol Waste through Production of Single Cell Oil and Citric Acid by Yarrowia lipolytica," Lipid Technology, Vol. 21, No. 4, 2009, pp. 83-87. doi:10.1002/lite.200900017

[13] S. K. Moon, Y. J. Wee, J. S. Yun and H. W. Ryu, "Production of Fumaric Acid Using Rice Bran and Subsequent Conversion to Succinic Acid through a Two-Step Process," Applied Biochemistry and Biotechnology, Vol. 115 , No. $1-3,2004$, pp. 843-856. doi:10.1385/ABAB:115:1-3:0843

[14] P. V. Arruda and M. G. Felipe, "Role of Glycerol Addition on Xylose-to-Xylitol Bioconversion by Candida guilliermondii," Current Microbiology, Vol. 58, No. 3, 2008, pp. 274-278. doi:10.1007/s00284-008-9321-7

[15] P. F. F. Amaral, T. F. Ferreira, G. C. Fontes and M. A. Z. Coelho, "Glycerol Valorization: New Biotechnological Routes," Food and Bioproducts Processing, Vol. 87, No. 3, 2009, pp. 179-186. doi:10.1016/j.fbp.2009.03.008

[16] S. Koganti, T. M. Kuo and C. P. Kurtzman, "Production of Arabitol from Glycerol: Strain Screening and Study of Factors Affecting Production Yield," Applied, Microbiology and Cell Physiology, Vol. 90, No. 1, 2011, pp. 257267.

[17] R. Bodarski, T. Wertelecki, F. Bommer and S. Gosiewski, "The Changes of Metabolic Status and Lactation Performance in Dairy Cows under Feeding TMR with Glycerin (Glycerol) Supplement at Periparturient Period," Electronic Journal of Polish Agricultural Universities, Vol. 8, No. 4, 2005.

[18] F. Barbirato, E. H. Himmi, T. Conte and A. Bories, "1,3-Propanediol Production by Fermentation: An Interesting Way to Valorize Glycerin from the Ester and Ethanol Industries," Industrial Crops and Products, Vol. 7, No. 2-3, 1998, pp. 281-289. doi:10.1016/S0926-6690(97)00059-9

[19] T. Haas, B. Jaeger, R. Weber, S. F. Mitchell and C. F. King, "New Diol Processes: 1,3-Propanediol and 1,4-Butanediol," Applied Catalysis A: General, Vol. 280, No. 1, 2005, pp. 83-88. doi:10.1016/j.apcata.2004.08.027

[20] R. K. Saxena, P. Anand, S. Saran and J. Isar, "Microbial Production of 1,3-Propanediol: Recent Developments and 
Emerging Opportunities," Biotechnology Advances, Vol. 27, No. 6, 2009, pp. 895-913. doi:10.1016/j.biotechadv.2009.07.003

[21] S. Papanikolaou, S. Fakas, M. Fick, I. Chevalot, M. Galiotou-Panayotou, M. Komaitis, I. Marc and G. Aggelis, "Biotechnological Valorisation of Raw Glycerol Discharged after Bio-Diesel (Fatty Acid Methyl Esters) Manufacturing Process: Production of 1,3-Propanediol, Citric Acid and Single Cell Oil," Biomass and Bioenergy, Vol. 32, No. 1, 2008, pp. 60-71. doi:10.1016/j.biombioe.2007.06.007

[22] M. Metsoviti, S. Paramithiotis, E.H. Drosinos, M. Galiotou-Panayotou, G. J. E. Nychas, A. P. Zeng and S. Papanikolaou, "Screening of Bacterial Strains Capable of Converting Biodiesel-Derived Raw Glycerol into 1,3-Propanediol, 2,3-Butanediol and Ethanol," Engineering in Life Sciences, Vol. 12, No. 1, 2012, pp. 57-68. doi:10.1002/elsc.201100058

[23] A. Freund, "Über die Bildung und Darstellung von Trimethylenalkohol aus Glycerin," Monatshefte für Chemie, Vol. 2, No. 1, 1881, pp. 636-641. doi:10.1007/BF01516545

[24] B. Sims, "Clearing the Way for Byproduct Quaity," 2011. http://www.biodieselmagazine.com/articles/8137/clearing -the-way-forbyproduct-quality

[25] H. Biebl, K. Menzel, A. P. Zeng and W. D. Deckwer, "Microbial Production of 1,3-Propanediol," Applied Microbiology and Biotechnology, Vol. 52, No. 3, 1999, pp. 289-297. doi:10.1007/s002530051523

[26] T. Willke and K. Vorlop, "Biotransformation of Glycerol into 1,3-Propanediol," European Journal of Lipid Science and Technology, Vol. 110, No. 9, 2008, pp. 831-840. doi:10.1002/ejlt.200800057

[27] A. Drożdżyńska, K. Leja and K. Czaczyk, "Biotechnological Production of 1,3-Propanediol from Crude Glycerol," Journal of Biotechnology, Computational Biology and Bionanotechnology, Vol. 92, No. 1, 2011, pp. 92-100.

[28] E. L. Himmi, A. Bories and F. Barbirato, "Nutrient Requirements for Glycerol Conversion to 1,3-Propanediol by Clostridium butyricum," Bioresource Technology, Vol. 67, No. 2, 1999, pp. 123-128. doi:10.1016/S0960-8524(98)00109-6

[29] A. Suau, R. Bonnet, M. Sutren, J. J. Godon, G. R. Gibson, M. D. Collins and J. Dore, "Direct Analysis of Genes Encoding 16S rRNA from Complex Communities Reveals Many Novel Molecular Species within Human Gut," Applied Environmental Microbiology, Vol. 65, No. 11, 1999, pp. 4799-4807.

[30] S. F. Altschul, W. Gish, W. Miller, E. W. Myers and D. J. Lipman, "Basic Local Alignment Search Tool," Journal of Molecular Biology, Vol. 215, No. 3, 1990, pp. 403410. doi:10.1016/S0022-2836(05)80360-2

[31] K. Tamura, J. Dudley, M. Nei and S. Kumar, "MEGA4: Molecular Evolutionary Genetics Analysis (MEGA) Software Version 4.0.," Molecular Biology and Evolution, Vol. 24, No. 8, 2007, pp. 1596-1599. doi:10.1093/molbev/msm092

[32] H. Biebl and C. Spröer, "Taxonomy of the Glycerol Fermenting Clostridia and Description of Clostridium diolis sp.nov," Systematic and Applied Microbiology, Vol. 25,
No. 4, 2002, pp. 491-497. doi: $10.1078 / 07232020260517616$

[33] A. R. Hippen, J. M. DeFarin and P. L. Linke, "Glycerol and Other Energy Sources for Metabolism and Production of Transition Dairy Cows," Florida Ruminant Nutrition Symposium, Gainesville, 29-30 January 2008, pp. 1-17.

[34] M. DeFrain, A. R. Hippen, K. F. Kalscheur and P. W. Jardon, "Feeding Glycerol to Transition Dairy Cows: Effects on Blood Metabolites and Lactation Performance," Journal of Dairy Science, Vol. 87, No. 12, 2004, pp. 41954206. doi:10.3168/jds.S0022-0302(04)73564-X

[35] M. Gungormusler, C. Gonen, G. Ozdemir and N. Azbar, "1,3-Propanediol Production Potential of Clostridium saccharobutylicum NRRL B-643," New Biotechnology, Vol. 27, No. 6, 2010, pp. 782-788. doi:10.1016/j.nbt.2010.07.010

[36] C. M. Veiga and M. A. Foster, "1,3-Propanediol: NAD ${ }^{+}$ Oxidoreductase of Lactobacillus brevis and Lactobacillus buchneri," Journal of Bacteriology, Vol. 174, No. 3, 1992, pp. 1013-1019.

[37] G. Garai-Ibabe, I. Ibarburu, I. Berregi, O. Claisse, A. Lonvaud-Funel, A. Irastorza and M. T. Dueñas, "Glycerol Metabolism and Bitterness Producing Lactic Acid Bacteria in Cidermaking," Internationale Journal of Food Microbiology, Vol. 121, No. 3, 2008, pp. 253-261. doi:10.1016/j.ijfoodmicro.2007.11.004

[38] S. Pflügl, H. Marx, D. Mattanovich and M. Sauer, "1,3-Propanediol Production from Glycerol with Lactobacillus diolivorans," Bioresource Technology, Vol. 119, 2012, pp. 133-140. doi:10.1016/j.biortech.2012.05.121

[39] A. Rehman, M. Matsumura, N. Nomura and S. Sato, "Growth and 1,3-Propanediol Production on Pre-Treated Sunflower Oil Bio-Diesel Raw Glycerol Using a Strict Anaerobe Clostridium butyricum," Current Research in Bacteriology, Vol. 1, No. 1, 2008, pp. 7-16. doi:10.3923/crb.2008.7.16

[40] A. Chatzifragkou, S. Papanikolau, D. Dietz, A. I. Doulgeraki, G. J. E. Nychas and G. J. E. Zeng, "Production of 1,3-Propanediol by Clostridium butyricum Growing on Biodiesel-Derived Crude Glycerol through a Non-Sterilized Fermentation Process," Applied Microbiology and Biotechnology, Vol. 91, No. 1, 2011, pp. 101-112. doi;10.1007/s00253-011-3247-x

[41] A. K. Ringel, E. Wilkens, D. Hortig, T. Willke and K. D. Vorlop, "An Improved Screening Method for Microorganisms Able to Convert Crude Glycerol to 1,3-Propanediol and to Tolerate High Product Concentrations," Applied Microbiology and Biotechnology, Vol. 93, No. 3, 2012, pp. 1049-1056. doi:10.1007/s00253-011-3594-7

[42] K. Venkataramanan, J. Boatman, Y. Kurniawan, G. Taconi, G. Bothun and C. Scholz, "Impact of Impurities in Biodiesel-Derived Crude Glycerol on the Fermentation by Clostridium pasteurianum ATCC 6013," Applied Microbiology and Biotechnology, Vol. 93, No. 3, 2012, pp. 1325-1335. doi;10.1007/s00253-011-3766-5

[43] S. Papanikolaou, P. Ruiz-Sanchez, B. Pariset, F. Blanchard and M. Fick, "High Production," Journal of Biotechnology, Vol. 77, No. 2-3, 2000, pp. 191-208. doi:10.1016/S0168-1656(99)00217-5 
[44] T. Colin, A. Bories and G. Moulin, "Inhibition of Clostridium butyricum by 1,3-Propanediol and Diols during Glycerol Fermentation," Applied Microbiology and Biotechnology, Vol. 54, No. 2, 2000, pp. 201-205. doi: $10.1007 / \mathrm{s} 002530000365$

[45] M. González-Pajuelo, J. C. Andrade and I. Vasconcelos, "Production of 1,3-Propanediol by Clostridium butyricum VPI 3266 Using a Synthetic Medium and Raw Glycerol," Journal of Industrial Microbiology and Biotechnology, Vol. 31, No. 9, 2004, pp. 442-446. doi:10.1007/s10295-004-0168-z

[46] T. Colin, A. Bories, C. Lavigne and G. Moulin, "Effect of Acetate and Butyrate during Glycerol Fermentation by Clostridium butyricum," Current Microbiology, Vol. 43, No. 4, 2001, pp. 238-243. doi:10.1007/s002840010294

[47] G. Kaur, A. K. Srivastava and S. Chand, "Simple Strategy of Repeated Batch Cultivation for Enhanced Production of 1,3-Propanediol Using Clostridium diolis," Applied Biochemistry and Microbiology, Vol. 167, No. 5, 2012, pp. 1061-1068. 